\title{
Critical Analysis of Risk Factors Associated with Depression Among Patients with Chronic Kidney Disease: A Systematic Review
}

\author{
Faruk Namalam ${ }^{2 *}$ and Chris Papadopoulos ${ }^{1}$ \\ ${ }^{1}$ Public Health Faculty of Health and Social sciences \\ ${ }^{2}$ Director health planning research \& statistic sokoto state primary health care development agency, and program manager emergency \\ routine immunization coordination center sokoto, Nigeria \\ *Corresponding author: Faruk Namalam, Director health planning research \& statistic sokoto state primary health care develop- \\ ment agency, and program manager emergency routine immunization coordination center sokoto, Nigeria
}

\begin{abstract}
ARTICLE INFO
Received: 悪 March 01, 2019

Published: March 13, 2019

Citation: Faruk Namalam, Chris Papadopoulos. Critical Analysis of Risk Factors Associated with Depression Among Patients with Chronic Kidney Disease: A Systematic Review. Biomed J Sci \& Tech Res 15(5)-2019. BJSTR. MS.ID.002775.
\end{abstract}

Keywords: Risk Factors; Depression; CKD (Chronic Kidney Disease)
ABSTRACT

Background: Chronic kidney disease (CKD) is progressive and advance medical condition in which the kidneys fail to perform their primary functions. The occurrence of CKD is on the increase globally which made it a public health issue. Depression among CKD patients is a complex and common phenomenon. The complexity of depression in CKD is associated with the similarities between depressive and uremic symptoms.

Aim: The aim of this study is to conduct a critical and systematic analysis with a view to reviewing studies in order to identify the risk factors that are associated with depression in CKD.

Methods: The study design is a systematic review in which 648 articles were accessed and evaluated. During the course screening and evaluation15 primary articles relevant to the research question were selected and appraised using quality appraisal framework. During the quality appraisal 4 primary articles were excluded due to low quality.

Findings: Of the 11 primary articles included, 20 risk factors relevant to the research question were identified in which 18 risk factors were significant while, 2 were not significant. Narrative analysis of data was conducted because the included studies are heterogeneous.

Conclusion: Depression is common among CKD patients and is associated with variety of significant risk factors.

\section{Introduction}

Kidneys are very important organs in human body because of the roles they play in carrying out excretory and endocrine functions in our body [1]. According to Levey et al. [2] chronic kidney disease (CKD) refers to insidious renal damage or impairment in renal function characterised by decreased glomerular function below $60 \mathrm{ml} /$ minute per 1.73 square metre for more than 3 months in respective of causative agent or risk factor. Pagels et al. [3] argue that, CKD is classified into 5 main stages in line with the level of glomerular malfunction or renal impairment: Stage 1, established renal damage with normal or abnormal renal function, with glomerular filtration exceeding $90 \mathrm{mls}$ per minute per 1.73 square metre; stage 2, mild decrease in renal function, with glomerular filtration rate less than 60 to $89 \mathrm{mls}$ per minute per 1.73 square metre; stage 3 , a moderate impairment of kidney function due to damage to the renal cells, with glomerular filtration below $30-59 \mathrm{mls}$ per minute per 1.73 square metre; stage 4, extreme reduction of kidney function, with glomerular filtration less than $15-29 \mathrm{mls}$ per minute per 1.73 square metre; stage 5, a loss of kidney function, with glomerular filtration below $15 \mathrm{mls}$ per minute per 1.73 square metre. At this stage renal function cannot be restored hence, patients are initiated to renal dialysis or possible kidney transplant. It has been suggested by Chiang et al. (2013), that chronic kidney disease 
is a global public health issue with an increased in occurrence rate of over two million cases in 2010. Schieppati \& Remuzzi [4] asserts that chronic kidney disease is often under detected as a result of inadequate measures to evaluate its impact; Schieppati \& Remuzzi further observed genitourinary track infections are responsible for about 15,010,167 reduce quality of life associated with the disease morbidity and an estimated primary cause of death of about 850,000 people annually around the globe. Wenet al's prospective study further illustrates the epidemiology and public health impact that CKD has upon mortality rates, they sampled 462,293 people, ages 20 and above in Taiwan. Further, from the sample, 12.3\% are cases, while $87.7 \%$ are control groups. The study aimed to measure the prevalence and mortality rates associated with CKD among Taiwanese population. The researchers also found that of the total study population only $3.54 \%$ had prior knowledge of their CKD status, and that the study showed that CKD is responsible for up to $10 \%$ mortality which is the same with obesity and tobacco smoking (Wen et al. 2008).The researchers also found that CKD was under reported and that it had a negative impact on the socioeconomic status of victims. The authors concluded that CKD and its impact are of significant concern to public health. Mcmh, Thabet \& Vostanis [5-10] reported that depression in CKD is pronounce and that it has a negative impact on the wellbeing of patients diagnosed with CKD. Cukor et al. [11] adds that while patients diagnosed with irreversible kidney disease are often depressed, making a formal diagnosis of depression can be challenging and complex due to significant symptomatic overlap between uremic and depressive symptoms in CKD.

\section{Methods}

This study is a secondary research; hence the method used is systematic review of primary articles which are relevant to the research question. Ethical approval was granted to carry out this study as a secondary research by the Ethic Committee of the University of Bedfordshire. During the course of study identification, the following inclusion and exclusion criteria were adopted; primary articles, patients with chronic kidney disease and risk factors of depression among CKD patients, articles examining the correlation between depression and chronic kidney disease, articles published in English language and are within 10 years between 2004 and 2014 are included. Articles which are secondary, not on chronic kidney patients, articles that does not examine depression among patients with chronic kidney disease, articles that does not examine the correlation and/or association between depression and CKD, articles which are published not in English language and those published prior to 2004 were excluded.

\section{Searching Strategy and Study Selection Process}

A few relevant electronic databases which include; CINAHL, PUBMED, Psychinfo and AMED were considered. This is with a view to answering the research question in line with the laid down study criteria (Hek, Judd \& Moule, 2002). However, PUBMED electronic database was searched for this purpose using the following keywords and Boolean operators: 'Risk', 'Factors', 'Associated', 'Linked', 'Influencing,' 'Chronic kidney disease,' 'Depression', 'Depress', 'Mood disorder', 'Mental', 'Cognitive impairment', 'Contributing', 'Predisposing', 'Expose', 'Irreversible kidney disease', 'Failure', 'Damage', 'Injury', 'Prevalence', 'Incidence', 'Occurrence'. Booleanoperators: (Risk OR hazard OR contributing OR predisposing OR exposing OR influencing) AND (Factors OR determinants OR agents) AND (Associated OR linked) AND (Prevalence OR incidence OR occurrence) AND (Diagnosis OR Measures) AND (Depression) AND (Chronic renal failure OR chronic kidney disease OR irreversible kidney disease OR end stage renal disease).

\section{Data Extraction}

This technique allows for retrieving of relevant piece of information from primary journal articles. And the following headings were used for this purpose: Authors, year of publication, journal reference, title of journal/article, purpose of study, design of study, sampling, sample size, data collection method, identified examined risk factors of depression among CKD patients, statistical strengths of risk factors explaining depression among CKD patients, author's proposed limitations, recommendations and comments.

\section{Quality Appraisal}

This protocol is detailed towards evaluating the identified studies with a view to ascertaining the validity and reliability of each article selected for the study, using CASP's framework check list for cross-sectional and cohort studies. The protocol involves a rigorous and systematic process which is used to assess the weaknesses and strengths of the included studies based on their designs (Hek, Judd \& Moule [12]; Young \& Solomon [13]). During screening 13 primary articles were selected for the purpose of this study and two articles included from the references check list; and it was made explicit. Of the total 15 articles selected 12 are cross-sectional studies while three were cohort studies. In this review the quality appraisal was conducted in two phases according to the study design in order to achieve valid and reliable appraisal of the included studies in the review. Firstly, cross-sectional studies were appraised then the cohort studies using appropriate check list for quality appraisal. The adopted check lists used for quality appraisal are [14-20] for the cross sectional studies, and check list for cohort studies. A detail breakdown of the studies' appraisal can be found in Tables $1 \& 2$. 
Table 1: Quality appraisal of the included cross sectional studies.

\begin{tabular}{|c|c|c|c|c|c|c|c|c|c|c|c|}
\hline $\mathbf{S} / \mathbf{N}$ & $\begin{array}{c}\text { Study Authors and } \\
\text { year of publica- } \\
\text { tion }\end{array}$ & Study design & $\begin{array}{c}\text { Clarity } \\
\text { of sam- } \\
\text { pling } \\
\text { tech- } \\
\text { nique }\end{array}$ & $\begin{array}{l}\text { Sam- } \\
\text { ple } \\
\text { size }\end{array}$ & $\begin{array}{l}\text { Strength } \\
\text { of data } \\
\text { analysis }\end{array}$ & $\begin{array}{l}\text { Findings are } \\
\text { associated } \\
\text { with risk } \\
\text { factors for } \\
\text { depression } \\
\text { in CKD }\end{array}$ & $\begin{array}{l}\text { Statis- } \\
\text { tical } \\
\text { analysis } \\
\text { of study } \\
\text { findings }\end{array}$ & $\begin{array}{l}\text { Limita- } \\
\text { tions }\end{array}$ & $\begin{array}{l}\text { Rele- } \\
\text { vancy of } \\
\text { articles } \\
\text { to the } \\
\text { research } \\
\text { question }\end{array}$ & $\begin{array}{c}\text { Ethic } \\
\text { \&Study } \\
\text { time line } \\
(2004-14)\end{array}$ & Scoring \\
\hline 1 & Kang et al. [16] & $\begin{array}{l}\text { Cross-sec- } \\
\text { tional }\end{array}$ & Yes & 169 & Yes & Yes & Yes & Yes & Yes & Yes & Strong \\
\hline 2 & Afsar [17] & $\begin{array}{l}\text { Cross-sec- } \\
\text { tional }\end{array}$ & Yes & 109 & Yes & Yes & Yes & Yes & Yes & Yes & Strong \\
\hline 3 & $\begin{array}{c}\text { Nowak, } \\
\text { Adamczak\&Wiecek } \\
{[18]}\end{array}$ & $\begin{array}{l}\text { Cross-sec- } \\
\text { tional }\end{array}$ & Can't say & 694 & Yes & Yes & $\mathrm{n} / \mathrm{m}$ & Yes & Yes & Yes & $\begin{array}{l}\text { Moder- } \\
\text { ate }\end{array}$ \\
\hline 4 & Chen et al. [19] & $\begin{array}{c}\text { Cross-sec- } \\
\text { tional }\end{array}$ & Yes & 200 & Yes & Yes & Yes & Yes & Yes & Yes & Strong \\
\hline 5 & Park et al. [20] & $\begin{array}{l}\text { Cross-sec- } \\
\text { tional }\end{array}$ & Yes & 105 & Yes & Can't say & Yes & $\begin{array}{l}\text { Can't } \\
\text { say }\end{array}$ & Not clear & Yes & Weak \\
\hline 6 & Lopes et al. [21] & $\begin{array}{l}\text { Cross-sec- } \\
\text { tional }\end{array}$ & Yes & 868 & Yes & $\mathrm{n} / \mathrm{s}$ & Yes & $\mathrm{n} / \mathrm{m}$ & Yes & Yes & Strong \\
\hline 7 & Agganiset al. [22] & $\begin{array}{l}\text { Cross-sec- } \\
\text { tional }\end{array}$ & Yes & 241 & Yes & Yes & Yes & Yes & Yes & Yes & Strong \\
\hline 8 & Fernandeset al. [23] & $\begin{array}{l}\text { Cross-sec- } \\
\text { tional }\end{array}$ & Yes & 275 & Yes & No & Yes & Yes & No & Yes & Weak \\
\hline 9 & Amira [24] & $\begin{array}{l}\text { Cross-sec- } \\
\text { tional }\end{array}$ & Yes & 168 & Yes & Yes & Yes & Yes & Yes & Yes & Strong \\
\hline 10 & Chang et al. [25] & $\begin{array}{l}\text { Cross-sec- } \\
\text { tional }\end{array}$ & Yes & 270 & Yes & Yes & Yes & Yes & Yes & Yes & Strong \\
\hline 11 & Santos [26] & $\begin{array}{l}\text { Cross-sec- } \\
\text { tional }\end{array}$ & Not clear & 166 & Not clear & Can't say & Yes & Yes & Yes & Yes & Weak \\
\hline 12 & Sezeret al. [27] & $\begin{array}{l}\text { Cross-sec- } \\
\text { tional }\end{array}$ & Yes & 141 & Yes & yes & Yes & $\mathrm{n} / \mathrm{m}$ & Yes & Yes & $\begin{array}{l}\text { Moder- } \\
\text { ate }\end{array}$ \\
\hline
\end{tabular}

Table 2: Quality appraisal of the included cohort studies.

\begin{tabular}{|c|c|c|c|c|c|c|c|c|c|c|c|c|c|}
\hline$S / N$ & $\begin{array}{c}\text { Au- } \\
\text { thors \& } \\
\text { year of } \\
\text { publi- } \\
\text { cation }\end{array}$ & $\begin{array}{c}\text { Study } \\
\text { de- } \\
\text { sign }\end{array}$ & $\begin{array}{l}\text { Sam- } \\
\text { ple } \\
\text { size }\end{array}$ & $\begin{array}{l}\text { Charac- } \\
\text { teristics } \\
\text { Of study } \\
\text { groups } \\
\text { from the } \\
\text { popu- } \\
\text { lation } \\
\text { source }\end{array}$ & $\begin{array}{c}\text { Re- } \\
\text { sponse } \\
\text { of } \\
\text { partici- } \\
\text { pants }\end{array}$ & $\begin{array}{l}\text { Whether } \\
\text { some par- } \\
\text { ticipants } \\
\text { have } \\
\text { depres- } \\
\text { sion as an } \\
\text { outcome } \\
\text { of interest } \\
\text { during } \\
\text { recruit- } \\
\text { ment }\end{array}$ & $\begin{array}{c}\text { Com- } \\
\text { parative } \\
\text { analysis } \\
\text { between } \\
\text { partici- } \\
\text { pants who } \\
\text { completed } \\
\text { the study } \\
\text { and the } \\
\text { dropped } \\
\text { out at base } \\
\text { line }\end{array}$ & $\begin{array}{l}\text { Allocation } \\
\text { to groups: } \\
\text { exposed \& } \\
\text { unexposed }\end{array}$ & $\begin{array}{l}\text { Reli- } \\
\text { abil- } \\
\text { ity \& } \\
\text { valid- } \\
\text { ity of } \\
\text { study } \\
\text { find- } \\
\text { ings to } \\
\text { the re- } \\
\text { search } \\
\text { ques- } \\
\text { tion }\end{array}$ & $\begin{array}{l}\text { Inten- } \\
\text { sity of } \\
\text { risk } \\
\text { factors } \\
\text { associ- } \\
\text { ated to } \\
\text { depres- } \\
\text { sion in } \\
\text { CKD }\end{array}$ & $\begin{array}{l}\text { Analysis } \\
\text { of con- } \\
\text { found- } \\
\text { ers }\end{array}$ & $\begin{array}{l}\text { Eth- } \\
\text { ics }\end{array}$ & Score \\
\hline 1 & $\begin{array}{c}\text { Kell- } \\
\text { erman } \\
{[12]}\end{array}$ & $\begin{array}{l}\text { Pro- } \\
\text { spec- } \\
\text { tive } \\
\text { cohort }\end{array}$ & 359 & Not clear & $72 \%$ & $\mathrm{n} / \mathrm{m}$ & Not clear & $\mathrm{n} / \mathrm{m}$ & $\begin{array}{c}\text { Not } \\
\text { appli- } \\
\text { cable }\end{array}$ & $\begin{array}{l}\text { Not } \\
\text { applica- } \\
\text { ble }\end{array}$ & Yes & $\mathrm{n} / \mathrm{m}$ & $\begin{array}{l}\text { Reject- } \\
\text { ed }\end{array}$ \\
\hline 2 & $\begin{array}{l}\text { Kop } \\
{[13]}\end{array}$ & $\begin{array}{l}\text { Lon- } \\
\text { gitu- } \\
\text { dinal } \\
\text { cohort }\end{array}$ & 5785 & Clear & $77 \%$ & Clear & Yes & Yes & $\begin{array}{l}\text { Appli- } \\
\text { cable }\end{array}$ & $\begin{array}{l}\text { Appli- } \\
\text { cable }\end{array}$ & Yes & Yes & $\begin{array}{l}\text { High } \\
\text { qual- } \\
\text { ity }\end{array}$ \\
\hline 3 & $\begin{array}{c}\text { Young } \\
{[14]}\end{array}$ & $\begin{array}{l}\text { Pro- } \\
\text { spec- } \\
\text { tive } \\
\text { cohort }\end{array}$ & 4128 & Clear & $70 \%$ & Clear & Yes & Yes & $\begin{array}{l}\text { Appli- } \\
\text { cable }\end{array}$ & $\begin{array}{c}\text { Appli- } \\
\text { cable }\end{array}$ & $\mathrm{n} / \mathrm{m}$ & Yes & $\begin{array}{l}\text { Ac- } \\
\text { cept- } \\
\text { able }\end{array}$ \\
\hline
\end{tabular}




\section{Outcomes of Quality Appraisal}

The quality appraisal conducted focused clearly on evaluating the selected articles with a view to answering the research question. A total of 15 articles were appraised out which 11 articles passed the quality appraisal protocol whereas, four articles were excluded because they did not meet the criteria. The strategy used for the quality appraisal was strictly based on CAPS check list parameters; in order to evaluate each study based on its methodological quality and it relevance to the research question. Similarly, the articles were also appraised in line with the inclusion criteria of the study. Of those articles which passed the quality appraisal nine were crosssectional studies and two cohort studies. Six of the cross-sectional studies have $100 \%$ response of the participants, the studies are as follows. All these studies have appropriate study design and have met majority of the criteria for appraisal and they were all scored strong apart from one study by [21-26] which has unclear sampling technique and it was scored moderate. The remaining three articles are $84 \%$ response, $96.4 \%$ response and $51.6 \%$ response.

The first and second articles were scored strong because they have appropriately met majority of the criteria whereas, the third article in this group was scored moderate because of low response and unclear limitations however, the findings from this study are significant to the research question and were strongly associated with depression in CKD; besides, the study has appropriate design. The two cohort studies included are scored high because the study has $77 \%$ response and has met majority of the criteria. While the second article by Young et al. [27] was scored as acceptable because the authors have not clearly analyses the study confounders, but the study has $70 \%$ response which is good. It states that response rate in research is flexible, however the author suggested that $75 \%$ or more is a good response rate. The studies excluded from quality appraisal are [28-35] these articles were rejected because they have not met the criteria for quality appraisal and the findings from these studies were found to be irrelevant to the research question.

\section{Data analysis}

All the included studies screened and evaluated were collated and synthesized in order to answer the research question. The included studies referred to those studies which passed the inclusion criteria for this review. It has been suggested by Polit \& Beck [36] that data analysis is the process of synthesizing and appraising of data from selected studies that are extracted and evaluated based on quality appraisal framework aims at answering a research question. Therefore, the analysis focused on the study population, allo- cation of participants to groups according to the study design, and the study findings with a view to achieving a contextual analysis which is referred to as discourse appraisal of data [37-40]. Moreover, for the purpose of this study a narrative analysis was chosen because the included studies for this review involved studies with different study designs which make narrative analysis more appropriate than meta-analysis Lucas et al. [41]. Similarly, narrative analysis allows for a reflexive and detailed critical appraisal of data compared to meta-analysis. These qualities make narrative analysis more appropriate and suitable for this study. The process of data analysis was undertaken in a structured manner, using Popay et al. [42] framework guidelines for narrative analysis.

\section{Descriptive Results}

As can be seen in Figure 1 below a total of 648 articles were retrieved through an electronic search process from Pub-med. Of the 648 articles 68 articles passed the title and abstract screening; while during the full text screening only 13 articles satisfied the inclusion and exclusion criteria of the study and were included in the study for analysis. Also, 2 articles were selected from the references check list, which brought the total number of articles selected for quality appraisal to 15 . The 15 selected articles were appraised, and final selection was made which resulted in the exclusion of four additional articles due to low quality; which brought the total number of studies selected to eleven. The articles selected from the quality appraisal identified risk factors associated with depression among CKD patients which implies that, most of the findings from the articles revealed significant association between the identified risk factors and depression among CKD patients. Descriptive background of each study's key information, methodology and key results are given in table3 below. The descriptive background is aimed to inform the readers on the characteristics of each of the included study in this review. Of the total 11 studies included four of them were from the United States of America the studies are [4350] Two of the studies were conducted in Asia precisely Taiwan. One study by Lopes et al. (2010) was conducted in Brazil from Latin America; similarly, only one study is from Africa which was conducted from Nigeria in West Africa. Whereas, three of the studies were from Europe; two of the studies were from Turkey and one of the studies by Nowak, conducted in Poland. All the studies included in this review were on CKD (Chronic kidney disease); besides, four of the studies considered treatment modalities in CKD specifically dialysis and how it influences the incidence of depression in CKD. Nine of the included studies used cross-sectional designs and two of the studies used cohort study designs. 


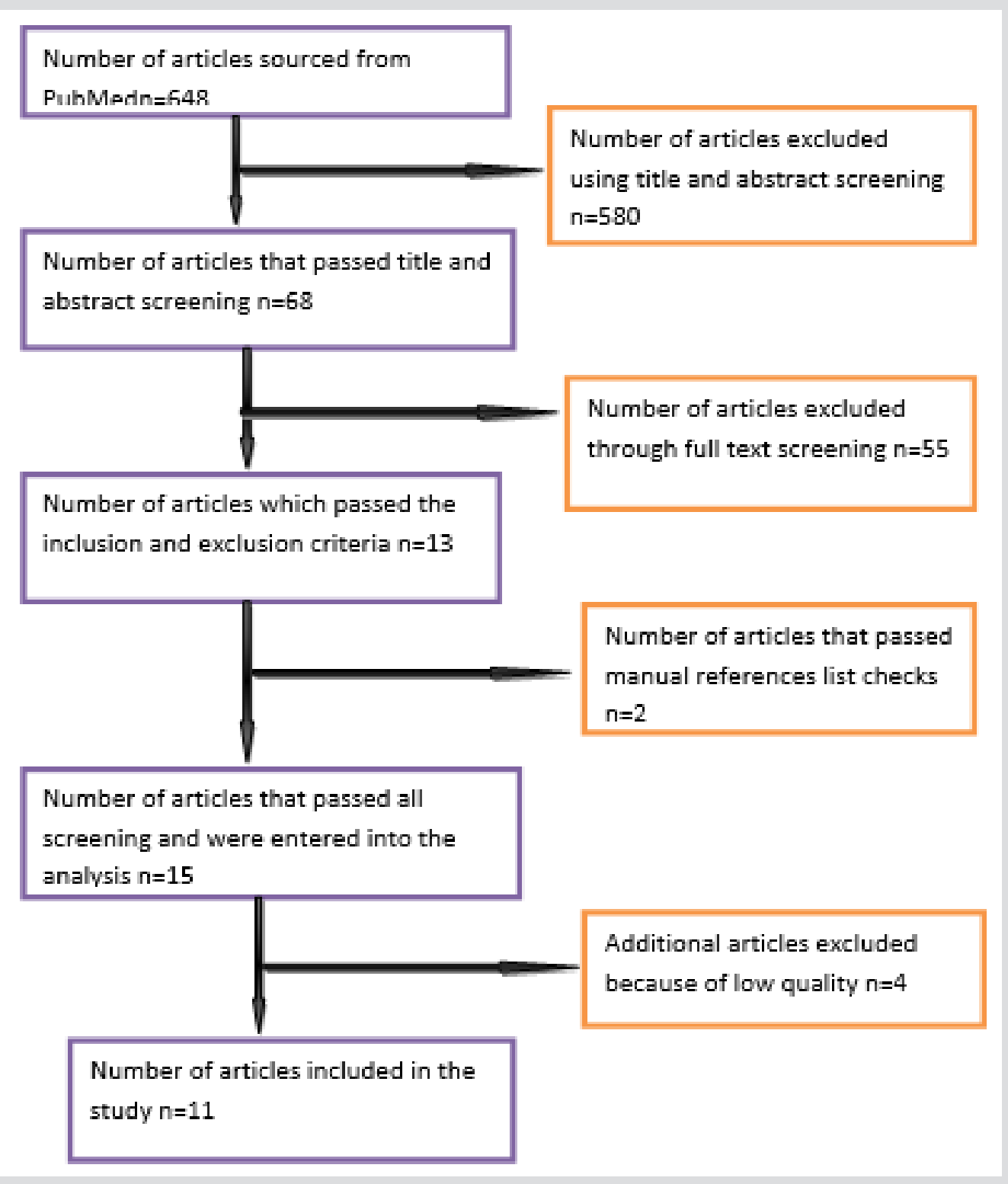

Figure 1: Flow chat for study selection process.

\section{Types of Identified Risk Factors}

The majority of the findings from the included studies were relevant to the research question and have significant association with depression in CKD. To start with, the studies conducted [51$56]$ in Table 3 below both looked at clinical variables as the key data in their results. It identifies low testosterone level among male patients with CKD as the key significant risk factor to depression, while reveals that low urea clearance due to inadequate dialysis and low serum albumin as the risk factors to depression among CKD patients irrespective gender [57-60] however the measurement outcome was not significant in Agganis et al's. study. Whereas, Chen et al. (2010) in their study identifies low quality of life (LQoL) and low Body mass index (LBMI) as the key risk factors of depression in CKD. Furthermore, Amira (2011) identifies treatment burden attached to RRT (Renal replacement therapy) as significant risk factor to depression in CKD. While, maintained that patients who are dependent on care providers and patients who have lager family to look after are likely to be depressed. On the other hand, the studies found that gender, sleep disorder, lack of exercise, race, education, temporary vascular access, frequent hospital admissions, age and marital status of CKD patients are significant risk factors linked with the occurrence of depression in CKD. Though, the findings in which the former investigated sleep disorder as a risk factor and the later investigated age as risk factor of depression in CKD were not significant. Detail breakdown of the actual level of the identified risk factors from the included studies can be found in Table 4 . 
Table 3: Descriptive information of key results and methodological details of the included studies.

\begin{tabular}{|c|c|c|c|c|c|c|}
\hline & $\begin{array}{l}\text { Author \& } \\
\text { date }\end{array}$ & $\begin{array}{l}\text { Demography } \& \text { char- } \\
\text { acteristics of subjects }\end{array}$ & $\begin{array}{c}\text { Study design \& } \\
\text { aim }\end{array}$ & Sampling procedure & $\begin{array}{l}\text { Outcome measure- } \\
\text { ment tools }\end{array}$ & Key results \\
\hline 1 & Afsar [21] & $\begin{array}{c}\text { Study conducted at } \\
\text { Konya Numune medical } \\
\text { centre in Turkey. Male } \\
\text { patients diagnosed } \\
\text { with CKD, } n=109 \text {, age= } \\
52.6+/-13.7, \text { marital } \\
\text { status: } 105 \text { married, } 4 \\
\text { not married. }\end{array}$ & $\begin{array}{l}\text { Cross-sectional } \\
\text { quantitative } \\
\text { survey study. } \\
\text { Investigating the } \\
\text { impact of serum } \\
\text { testosterone (male } \\
\text { sex hormone) level } \\
\text { as a potential risk } \\
\text { factor of depres- } \\
\text { sion in patients } \\
\text { diagnosed with } \\
\text { CKD. }\end{array}$ & $\begin{array}{l}\text { Participants were randomly } \\
\text { selected from a single centre nephrology } \\
\text { unit. A total of } 109 \text { patients were re- } \\
\text { cruited to take part in the study. Patients } \\
\text { were selected if they are diagnosed } \\
\text { with CKD stage } 3,4 \& 5 \text {, not on renal } \\
\text { replacement therapy and have given } \\
\text { their informed consent to take part in } \\
\text { the study. The diagnosis and the stages of } \\
\text { CKD were measured through laboratory } \\
\text { analysis of creatinine clearance (CrCl), } \\
\text { in addition to patients' previous health } \\
\text { history and physical examination. }\end{array}$ & $\begin{array}{l}\text { A } 21 \text { items Beck depres- } \\
\text { sion inventory (BDI) } \\
\text { questionnaire was used } \\
\text { to measure the level of } \\
\text { depression among study } \\
\text { participants. The score } \\
\text { for BDI ranges from } \\
0-63 \text {. }\end{array}$ & $\begin{array}{l}\text { Low serum testoster- } \\
\text { one in male adults } \\
\text { patients diagnosed } \\
\text { with CKD is a signif- } \\
\text { icant risk factor for } \\
\text { depression among } \\
\text { these groups of pa- } \\
\text { tients in respective } \\
\text { of their age. }\end{array}$ \\
\hline 2 & $\begin{array}{c}\text { Agganiset } \\
{[22]}\end{array}$ & $\begin{array}{l}\text { Study conducted in the } \\
\text { USA at } 5 \text { dialysis units } \\
\text { in Boston. } 51 \% \text { of the } \\
\text { study participants } \\
\text { were males whereas, } \\
49 \% \text { were females. } \\
\text { Race }=21.6 \% \text { African } \\
\text { Americans. Age in } \\
\text { years } 63.8+/-16.6 \text {. } \\
\text { Participants were } \\
\text { randomly selected } \\
\text { from five haemodialy- } \\
\text { sis centres (n=241) in } \\
\text { Boston. }\end{array}$ & $\begin{array}{l}\text { Cross-sectional } \\
\text { study. } \\
\text { The study aims } \\
\text { to investigate the } \\
\text { influence of demo- } \\
\text { graphics and the } \\
\text { characteristics of } \\
\text { patients diagnosed } \\
\text { with CKD and the } \\
\text { impact it has on } \\
\text { the occurrence of } \\
\text { depression among } \\
\text { the study group. }\end{array}$ & $\begin{array}{l}\text { The criteria for selection are patients } \\
\text { diagnosed with irreversible kidney } \\
\text { disease, on maintenance renal replace- } \\
\text { ment therapy, having adequate dialysis } \\
\text { with urea clearance greater than one } \\
\text { (Kt/V: }>1.0) \text {, not in a state of -dementia } \\
\text { or confusion during recruitment. Also, } \\
\text { participants are included if they are } \\
\text { fluent in English language and gave } \\
\text { their informed consent to participate } \\
\text { in the study. Participants' demographic } \\
\text { data was used to source for information } \\
\text { regarding their medical details and } \\
\text { characteristics. }\end{array}$ & $\begin{array}{l}\text { Depression was mea- } \\
\text { sured using a centre } \\
\text { for epidemiological } \\
\text { studies-depression scale } \\
\text { (CES-D). The measure- } \\
\text { ment was based on the } \\
\text { characteristics of the } \\
\text { participants, subjects } \\
\text { who have CES-D score } \\
\text { above } 16 \text { scale may } \\
\text { likely suffer from de- } \\
\text { pression. }\end{array}$ & $\begin{array}{l}\text { The results suggest- } \\
\text { ed that the identified } \\
\text { clinical variables } \\
\text { are risk factors } \\
\text { associated with } \\
\text { depression among } \\
\text { the study groups. } \\
\text { The identified vari- } \\
\text { ables are low serum } \\
\text { albumin and low } \\
\text { urea clearance due } \\
\text { to inadequate RRT. } \\
\text { The measurement } \\
\text { outcome yielded } \\
\text { insignificant result. }\end{array}$ \\
\hline 3 & Amira [23] & $\begin{array}{l}\text { The study was carried } \\
\text { out at a teaching } \\
\text { hospital in Lagos, } \\
\text { Nigeria. Comprised } \\
\text { of male ( } \mathrm{n}=73 \text { ) and } \\
\text { female ( }=45) \text {. Total } \\
\mathrm{n}=118 \text { patients diag- } \\
\text { nosed with CKD, aged } \\
\text { between } 42+/-14 \text { in } \\
\text { years. Fifty healthy in- } \\
\text { dividuals were selected } \\
\text { from among students } \\
\text { and members of staff of } \\
\text { the teaching hospital to } \\
\text { form the control group; } \\
52 \% \text { men and } 48 \% \\
\text { female. }\end{array}$ & $\begin{array}{l}\text { Cross-sectional } \\
\text { study. To examine } \\
\text { the determinants } \\
\text { of depression in } \\
\text { CKD. }\end{array}$ & $\begin{array}{l}\text { The participants for this study were } \\
\text { classified into case and control groups. } \\
\text { Demographic routine data and clinical } \\
\text { data were used to access the health } \\
\text { related issues about the case group. The } \\
\text { participants gave their informed consent } \\
\text { to partake in the study. }\end{array}$ & $\begin{array}{l}\text { The potential partici- } \\
\text { pants were served with } \\
20 \text { item questionnaires } \\
\text { as a tool for assessing } \\
\text { their level of depression } \\
\text { and its determinants } \\
\text { respectively. The } \\
\text { questionnaires were } \\
\text { translated into the local } \\
\text { dilate of the area, which } \\
\text { is Yoruba language } \\
\text { for the convenience of } \\
\text { participants who cannot } \\
\text { communicate in English. } \\
\text { The study compared the } \\
\text { status of CKD patients } \\
\text { before commencing re- } \\
\text { nal replacement therapy } \\
\text { (RRT) with those who } \\
\text { have transited onto RRT. }\end{array}$ & $\begin{array}{l}\text { The results indicated } \\
\text { that CKD patients } \\
\text { on RRT are34.5\% } \\
\text { likely to develop } \\
\text { depression, while } \\
\text { those not on RRT } \\
\text { are only } 13.3 \% \text { at } \\
\text { risk of developing } \\
\text { depression. This } \\
\text { suggested that RRT } \\
\text { is a significant risk } \\
\text { factor which influ- } \\
\text { ences depression in } \\
\text { CKD. The researcher } \\
\text { observed that, the } \\
\text { burden attached to } \\
\text { RRT is the major risk } \\
\text { factor linked with } \\
\text { depression in CKD. }\end{array}$ \\
\hline 4 & Chen [24] & $\begin{array}{l}\text { This study was con- } \\
\text { ducted at Chang Gung } \\
\text { hospital in Taiwan. } \\
\text { The study time line } \\
\text { was } 2007 \text { to } 2009 \text {. The } \\
\text { study population was } \\
200 \text { subjects diagnosed } \\
\text { with CKD on RRT age } \\
\text { above } 18 \text { years; } 53 \% \\
\text { of the population were } \\
\text { female and } 47 \% \text { were } \\
\text { male. }\end{array}$ & $\begin{array}{l}\text { This is a cross-sec- } \\
\text { tional study design } \\
\text { aims at investigat- } \\
\text { ing the associating } \\
\text { risk factors of } \\
\text { depression among } \\
\text { CKD patients on } \\
\text { RRT. }\end{array}$ & $\begin{array}{l}\text { Participants were randomly selected } \\
\text { from a single unit within the study } \\
\text { time frame. The participants consented } \\
\text { to take part in the study which was } \\
\text { approved by the Chang Gung hospital } \\
\text { ethics committee. }\end{array}$ & $\begin{array}{l}\text { The following measure- } \\
\text { ment tools were used to } \\
\text { assess and evaluate the } \\
\text { status of patients and } \\
\text { their level of depression, } \\
\text { the tools are: health } \\
\text { related quality of life } \\
\text { which assess mental } \\
\text { capacity and physical } \\
\text { function, chalder scale } \\
\text { for the assessment of } \\
\text { fatigue among dialysis } \\
\text { patients and depression } \\
\text { scale using hospital } \\
\text { anxiety and depression } \\
\text { assessment scale. }\end{array}$ & $\begin{array}{l}\text { The study outcomes } \\
\text { reveal that low body } \\
\text { mass index, fatigue } \\
\text { and low quality } \\
\text { of life due to poor } \\
\text { health, lost of social } \\
\text { function and anxiety } \\
\text { are significant risk } \\
\text { factors associated } \\
\text { with depression } \\
\text { among CKD patients } \\
\text { on RRT. }\end{array}$ \\
\hline
\end{tabular}




\begin{tabular}{|c|c|c|c|c|c|c|}
\hline 5 & Chiang [25] & $\begin{array}{l}\text { The study was con- } \\
\text { ducted in Taiwan at a } \\
\text { hospital located in the } \\
\text { southern part of the } \\
\text { country. Total of } 270 \\
\text { subjects diagnosed } \\
\text { with CKD were } \\
\text { enrolled out of which } \\
61 \% \text { were male and } \\
39 \% \text { were female. The } \\
\text { participants selected } \\
\text { have not commenced } \\
\text { RRT, but were attend- } \\
\text { ing a health facility. }\end{array}$ & $\begin{array}{l}\text { The study was a } \\
\text { cross-sectional } \\
\text { design which aims } \\
\text { to identify the } \\
\text { multiple variables } \\
\text { associated with } \\
\text { depression in CKD. }\end{array}$ & $\begin{array}{l}\text { Study participants were purposively } \\
\text { selected from a single centre in Taiwan. } \\
\text { The selection process took seven months } \\
\text { between January and August in the year } \\
\text { 2011. The participants were allocated } \\
\text { into groups as depressed and non-de- } \\
\text { pressed. }\end{array}$ & $\begin{array}{c}\text { Taiwanese depression } \\
\text { questionnaire which is } \\
18 \text { items questionnaire } \\
\text { was used as a measure- } \\
\text { ment tool to evaluate } \\
\text { depression among the } \\
\text { groups. }\end{array}$ & $\begin{array}{l}\text { Depression in CKD } \\
\text { is significantly } \\
\text { associated with } \\
\text { the severity of the } \\
\text { disease, also patients } \\
\text { with insomnia, those } \\
\text { who live sedentary } \\
\text { life and patients who } \\
\text { have no any religious } \\
\text { belief are likely to be } \\
\text { depressed. Similarly, } \\
\text { this study reveals } \\
\text { that gender is a } \\
\text { significant risk factor } \\
\text { associated with } \\
\text { depression in CKD as } \\
\text { female patients were } \\
\text { found to be more at } \\
\text { risk of developing } \\
\text { depression com- } \\
\text { pared to their male } \\
\text { counterparts in the } \\
\text { study. }\end{array}$ \\
\hline 6 & Kang [26] & $\begin{array}{l}\text { The study was carried } \\
\text { out in the United States } \\
\text { of America at a health } \\
\text { facility in Pittsburgh. } \\
\text { The researchers } \\
\text { recruited } 169 \text { subjects } \\
\text { diagnosed with CKD. } \\
\text { Of the total population } \\
34.9 \% \text { were female } \\
\text { and } 65.1 \% \text { were male, } \\
\text { within the ranges of } \\
18 \text { to } 90 \text { years; } 56.8 \% \\
\text { of the participants are } \\
\text { married. }\end{array}$ & $\begin{array}{l}\text { A cross-section- } \\
\text { al study set to } \\
\text { investigate the as- } \\
\text { sociation between } \\
\text { sleep disorder and } \\
\text { depression in CKD. }\end{array}$ & $\begin{array}{l}\text { Participants were routinely selected at } \\
\text { nephrology unit, RRT centre and renal } \\
\text { transplant unit within three years; from } \\
2004 \text { to } 2007 \text {. The subjects were divided } \\
\text { into two groups, those with sleep disor- } \\
\text { der (49.1\%) and those without sleep dis- } \\
\text { order ( } 50.9 \%) \text {. Information was sourced } \\
\text { through administrative questionnaire } \\
\text { and shot health related interview, also } \\
\text { routine data was collected through } \\
\text { participants' medical records. }\end{array}$ & $\begin{array}{l}\text { Depression was mea- } \\
\text { sured among the two } \\
\text { groups using } 9 \text { item } \\
\text { patient health question- } \\
\text { naires, or self reported } \\
\text { use of antidepressants } \\
\text { as intervention for } \\
\text { depression. }\end{array}$ & $\begin{array}{l}\text { The key finding from } \\
\text { this study show that } \\
\text { there is correlation } \\
\text { between sleep } \\
\text { disorder and the } \\
\text { onset of depression } \\
\text { among CKD patients } \\
\text { in stages } 4 \text { and } 5 .\end{array}$ \\
\hline 7 & Кор [27] & $\begin{array}{l}\text { The study was con- } \\
\text { ducted in the United } \\
\text { States of America } \\
\text { from four different } \\
\text { local communities. The } \\
\text { study population is } \\
5785,42.6 \% \text { were male } \\
\text { whereas, } 57.4 \% \text { were } \\
\text { female. The partici- } \\
\text { pants are from 65years } \\
\text { and above. }\end{array}$ & $\begin{array}{l}\text { This study is } \\
\text { a longitudinal } \\
\text { cohort study. The } \\
\text { aim of the study } \\
\text { is to observe the } \\
\text { association of } \\
\text { depression with } \\
\text { gender, marital } \\
\text { status, level of } \\
\text { education and race } \\
\text { among patients } \\
\text { with irreversible } \\
\text { kidney disease. }\end{array}$ & $\begin{array}{l}\text { The participants were randomly selected } \\
\text { from four communities in the USA. } \\
\text { The cohorts were assigned into two } \\
\text { groups depending on the level of their } \\
\text { depressive symptoms and they were } \\
\text { followed-up for } 14 \text { years. Participants } \\
\text { were excluded if they are not likely to be } \\
\text { residence in the area of study for three } \\
\text { years. Clinical data was collected via } \\
\text { interviews and questionnaire. Data on } \\
\text { hospital admissions during the follow- } \\
\text { up period were collected. }\end{array}$ & $\begin{array}{l}\text { During the course of the } \\
\text { study depression was } \\
\text { measured among the } \\
\text { study population using } \\
\text { centre for epidemiolog- } \\
\text { ic studies depression } \\
\text { scales which is10-item } \\
\text { measurement tool for } \\
\text { depression. }\end{array}$ & $\begin{array}{l}\text { The study reveals } \\
\text { that demographic } \\
\text { variables which } \\
\text { include: gender, } \\
\text { race, educational } \\
\text { and marital status } \\
\text { are significant risk } \\
\text { factors for depres- } \\
\text { sion in patients with } \\
\text { irreversible kidney } \\
\text { disease. }\end{array}$ \\
\hline 8 & Lopes [28] & $\begin{array}{l}\text { The study was conduct- } \\
\text { ed in Brazil at four dial- } \\
\text { ysis centres in Salvador. } \\
\text { The study comprises of } \\
868 \text { subjects diagnosed } \\
\text { with irreversible } \\
\text { disease who on RRT. } \\
\text { Of the total population } \\
59.1 \% \text { were male and } \\
40.9 \% \text { were female }\end{array}$ & $\begin{array}{l}\text { Cross-sectional } \\
\text { study. The aims } \\
\text { of the study is } \\
\text { to investigate } \\
\text { the correlation } \\
\text { between health } \\
\text { related quality of } \\
\text { life base on gender } \\
\text { and how it influ- } \\
\text { ence the onset of } \\
\text { depression among } \\
\text { the study groups. }\end{array}$ & $\begin{array}{l}\text { Participants were selected from four } \\
\text { in centre dialysis units in Brazilian city } \\
\text { Salvador. The researchers randomly } \\
\text { selected their subjects according to } \\
\text { the duration of treatment (Dialysis); } \\
16.5 \% \text { commenced RRT for }<3 \text { months, } \\
20.6 \% \text { commenced RRT for }>3 \text { months } \\
\text { and } 63 \% \text { were on RRT for }>12 \text { months. } \\
\text { These patients were observed for decline } \\
\text { quality of life and depression symptoms. } \\
\text { Also, the participants were assigned into } \\
\text { groups according to gender. }\end{array}$ & $\begin{array}{l}\text { The health related qual- } \\
\text { ity of life was measured } \\
\text { using Kidney disease } \\
\text { quality of life which is } \\
\text { a Portuguese version } \\
\text { shot form scale; and de- } \\
\text { pression was measured } \\
\text { using } 20 \text { item centre for } \\
\text { epidemiological stud- } \\
\text { ies-Depression scale. }\end{array}$ & $\begin{array}{l}\text { Gender is a signif- } \\
\text { icant risk factor } \\
\text { associated with } \\
\text { depression among } \\
\text { the study group. The } \\
\text { study reveals that } \\
\text { female are more at } \\
\text { risk because they } \\
\text { high score of depres- } \\
\text { sion compared male } \\
\text { patients. }\end{array}$ \\
\hline
\end{tabular}




\begin{tabular}{|c|c|c|c|c|c|c|}
\hline 9 & $\begin{array}{c}\text { Nowak, } \\
\text { Adamczak\& } \\
\text { Wiecek [29] }\end{array}$ & $\begin{array}{l}\text { This study was } \\
\text { conducted in a Polish } \\
\text { region of Silesia. A total } \\
\text { of } 694 \text { CKD patients } \\
\text { were recruited out of } \\
\text { which } 44.3 \% \text { are wom- } \\
\text { en and } 55.7 \% \text { are men } \\
\text { both participants are } \\
\text { on maintenance RRT. }\end{array}$ & $\begin{array}{l}\text { The study is a } \\
\text { cross-sectional } \\
\text { study which aims } \\
\text { to investigate } \\
\text { the associating } \\
\text { risk factors for } \\
\text { depression among } \\
\text { haemodialysis pa- } \\
\text { tients with CKD. }\end{array}$ & $\begin{array}{l}\text { Participants were recruited from } \\
\text { multicentre dialysis units across Silesia } \\
\text { region in Poland. Randomise sampling } \\
\text { method was used to select sample and } \\
\text { the selected subjects were assigned into } \\
\text { two groups, which are: depressed and } \\
\text { non-depressed. }\end{array}$ & $\begin{array}{l}\text { Beck depression inven- } \\
\text { tory scale for depression } \\
\text { was used to measure } \\
\text { depression among the } \\
\text { study groups. }\end{array}$ & $\begin{array}{l}\text { Patients with femo- } \\
\text { ral catheter, central } \\
\text { line or internal } \\
\text { jugular (temporary } \\
\text { access) high number } \\
\text { of hospital admis- } \\
\text { sions have greater } \\
\text { risk of developing } \\
\text { depression. Fur- } \\
\text { thermore, the study } \\
\text { reveals that patients } \\
\text { who are married are } \\
\text { less likely to develop } \\
\text { depression which } \\
\text { means the unmar- } \\
\text { ried are at risk to } \\
\text { develop depression. }\end{array}$ \\
\hline 10 & Sezer [30] & $\begin{array}{l}\text { The study was con- } \\
\text { ducted in Ankara the } \\
\text { Anatolian region of } \\
\text { the Turkish republic. } \\
\text { The study population } \\
\text { comprises of } 141 \\
\text { subjects, } 38.2 \% \text { of } \\
\text { them were female and } \\
61.8 \% \text { were men; who } \\
\text { were diagnosed with } \\
\text { CKD and have transited } \\
\text { on RRT. }\end{array}$ & $\begin{array}{l}\text { The study is a } \\
\text { cross-sectional } \\
\text { study. The study } \\
\text { aim is to investi- } \\
\text { gate socioenomic } \\
\text { risk factors } \\
\text { associated with } \\
\text { depression among } \\
\text { CKD patients who } \\
\text { are on RRT. }\end{array}$ & $\begin{array}{l}\text { In this cross-sectional study participants } \\
\text { were surveyed and selected. The criteria } \\
\text { for selection are: Patients diagnosed } \\
\text { with irreversible kidney disease, have } \\
\text { commenced RRT for more than three } \\
\text { months, not on psychiatry intervention } \\
\text { and are above } 18 \text { years and were able to } \\
\text { make an informed decision to partici- } \\
\text { pate. }\end{array}$ & $\begin{array}{l}\text { The measurement tool } \\
\text { used was Beck depres- } \\
\text { sion inventory scale. }\end{array}$ & $\begin{array}{l}\text { The study found } \\
\text { that CKD patients } \\
\text { who are on RRT are } \\
\text { faced with series of } \\
\text { physical, social and } \\
\text { economic challenges } \\
\text { which significantly } \\
\text { put them at greater } \\
\text { risk of developing } \\
\text { depression. }\end{array}$ \\
\hline 11 & Young [31] & $\begin{array}{l}\text { The study was con- } \\
\text { ducted in the USA in } \\
\text { Washington at nine } \\
\text { health facilities under } \\
\text { the Group Health. The } \\
\text { facilities are geograph- } \\
\text { ically located within } \\
\text { the radius of about } \\
40 \text {-miles of seattle. } \\
\text { The study population } \\
\text { is } 4128 \text { subjects out } \\
\text { of whom } 54.5 \% \text { were } \\
\text { male, } 36.4 \% \text { are single; } \\
\text { the average years of the } \\
\text { participants were } 65.5 \text {. }\end{array}$ & $\begin{array}{l}\text { The study was a } \\
\text { prospective cohort } \\
\text { study. The study's } \\
\text { aim is to identify } \\
\text { the association of } \\
\text { lack of exercise } \\
\text { and depression } \\
\text { considering the } \\
\text { characteristic of } \\
\text { cohort group in } \\
\text { the study. }\end{array}$ & $\begin{array}{l}\text { The researchers surveyed and recruited } \\
\text { subjects from multicentre non-profit } \\
\text { health facilities in the state of Washing- } \\
\text { ton. Participants were selected through } \\
\text { demographic data based on gender, race } \\
\text { and their ethnic background. Clinical } \\
\text { data was used to establish the causation } \\
\text { of the disease (CKD) since the study } \\
\text { focuses on patients with diabetic kidney. } \\
\text { The timeline for follow-up was } 6 \text { years, } \\
\text { from 2001-2007. }\end{array}$ & $\begin{array}{l}\text { A } 9 \text { item patient health } \\
\text { questionnaire was used } \\
\text { to determine major } \\
\text { depression and the level } \\
\text { of depression was mea- } \\
\text { sured using Diagnostic s } \\
\text { and Statistical Manual-4. }\end{array}$ & $\begin{array}{l}\text { The study shows that } \\
\text { sedentary life is a } \\
\text { significant risk factor } \\
\text { of depression among } \\
\text { CKD patients irre- } \\
\text { spective of causation, } \\
\text { gender and race of } \\
\text { the patient. }\end{array}$ \\
\hline
\end{tabular}




\begin{tabular}{|c|c|c|c|c|c|c|c|c|c|c|c|}
\hline 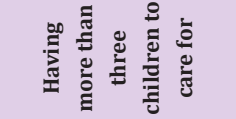 & & & & & & & & & & $\begin{array}{l}\overrightarrow{0} \\
0 \\
0 \\
\text { II } \\
\text { in }\end{array}$ & \\
\hline 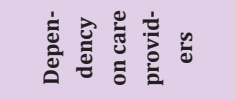 & & & & & & & & & & 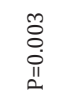 & \\
\hline 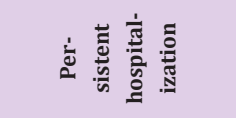 & & & & & & & & & $\begin{array}{l}\vec{\vdots} \\
\dot{b} \\
\text { in } \\
a\end{array}$ & & \\
\hline 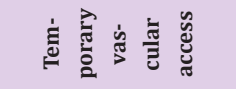 & & & & & & & & & $\begin{array}{l}\text { 蒿 } \\
0 \\
\text { iा } \\
\text { م. }\end{array}$ & & \\
\hline$\underset{\square}{\stackrel{0}{0}}$ & & & & & & & $\cong$ & & $\begin{array}{l}\text { Oे } \\
\text { i. } \\
\text { iI }\end{array}$ & & \\
\hline 穿总 & & & & & & & $\begin{array}{l}\overrightarrow{0} \\
\dot{0} \\
0 \\
\text { in } \\
\text { and }\end{array}$ & & & & \\
\hline 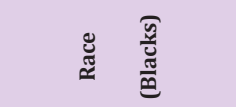 & & & & & & & $\begin{array}{l}\overrightarrow{0} \\
\dot{0} \\
\text { in } \\
a\end{array}$ & & & & \\
\hline 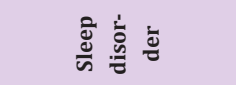 & & & & & $\begin{array}{l}\overrightarrow{0} \\
\dot{0} \\
0\end{array}$ & $\cong$ & & & & & \\
\hline 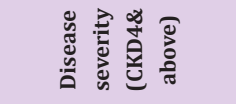 & & & & & $\begin{array}{l}\text { Õ. } \\
\text { in } \\
\text { n. }\end{array}$ & & & & & & \\
\hline 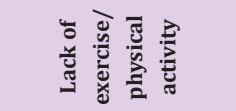 & & & & & 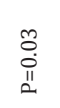 & & 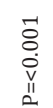 & & & & : \\
\hline 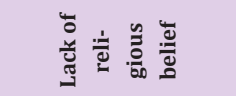 & & & & & $\begin{array}{l}\text { 兄 } \\
\text { iñ } \\
\text { In }\end{array}$ & & & & & & \\
\hline 咅 & & & & & $\begin{array}{l}\tilde{D} \\
\text { in } \\
\text { n. }\end{array}$ & & 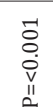 & & 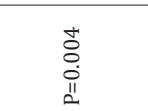 & & \\
\hline 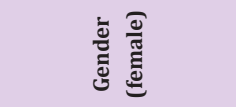 & & & & & $\begin{array}{l}m \\
\stackrel{0}{0} \\
\text { in }\end{array}$ & & $\begin{array}{l}\overrightarrow{0} \\
\dot{0} \\
\dot{0} \\
\text { م. }\end{array}$ & $\begin{array}{l}\overrightarrow{0} \\
\dot{0} \\
\text { in } \\
\text { a. }\end{array}$ & & & \\
\hline 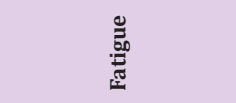 & & & & $\begin{array}{l}\overrightarrow{0} \\
\dot{0} \\
\text { II } \\
0\end{array}$ & & & & & & & \\
\hline 莺 & & & & $\begin{array}{l}\overrightarrow{0} \\
\dot{0} \\
\text { VI } \\
\text { II }\end{array}$ & & & & & & & \\
\hline 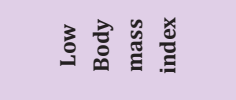 & & & & $\begin{array}{l}\overrightarrow{0} \\
0 \\
\text { In } \\
\text { In }\end{array}$ & & & & & & & \\
\hline 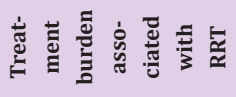 & & & $\begin{array}{l}\text { Lू } \\
\stackrel{0}{\| 1} \\
\text { L }\end{array}$ & & & & & & & & \\
\hline క气 & & $\cong$ & & & & & & & & & \\
\hline 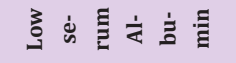 & & $\cong$ & & & & & & & & & \\
\hline 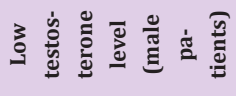 & $\begin{array}{l}\overrightarrow{0} \\
\text { iे } \\
\text { vi }\end{array}$ & & & & & & & & & & \\
\hline 聪 & 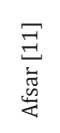 & 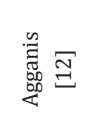 & 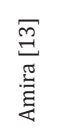 & 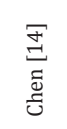 & 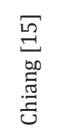 & 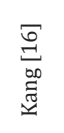 & 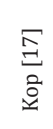 & 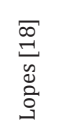 & 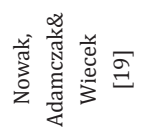 & 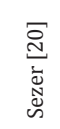 & $\begin{array}{l}\overrightarrow{\bar{d}} \\
\text { wo } \\
\text { 产 }\end{array}$ \\
\hline
\end{tabular}




\section{Results of Narrative Analysis}

\section{Physiological Risk Factors}

Three studies revealed physiological factors as significant risk factors which are mainly based on pathological transformations which occurred due to CKD or in some cases the risk factors may be secondary to the common invention (Dialysis) used in managing CKD. Specifically, these studies were found that depression among male patients diagnosed with CKD is strongly associated with decrease sexual function which is due to significant reduction in the level sex hormone among male patients with CKD [61-66]. The study of revealed that depression in CKD was associated with lower level of albumin and failure of the kidneys to excrete toxic waste or as a result of poor urea clearance from dialysis. Excess accumulation of toxic waste (urea) according to Agganis et al.'s study may affect the mental capacity of patients with CKD leading to high depressive symptoms and depression. However, the findings were not significant. The measurement outcome was not significant as it has been shown on Table 4 revealed that depression in chronic renal failure is associated with the extend of kidney damage identified insomnia as dependent risk factor associated with depression in CKD. Insomnia according to Kang et al.'s finding is likely secondary to fluid over load which may result to difficulty in breathing. Additionally, the result was not significant considering the measurement outcome.

\section{Physical Risk Factors}

The study is the only study which measured physical risk factors associated with depression in CKD. The focus group in Chen et al's study were CKD patients on maintenance renal dialysis; some of the physical risk factors identified are fatigue, low body mass index and low quality of life. These risk factors according to the findings are dependent risk factors, which are correlated with dialysis complications. Similarly, Chen et al noted that these risk factors are interrelated, and they have similar value according to the measurement scale used by the researchers.

\section{Socioeconomic Risk Factors}

The outcomes of narrative analysis show that social and economic factors are significant risk factors of depression in CKD. Specifically, studies conducted revealed that the social status of CKD patients plays vital role in the onset depression among these groups of patients. The analysis shows that CKD patients who leaves alone or those who are single have high depressive level compared to those who are married or lives with spouse. Additionally, explained that CKD patients who have large family to carter for and those who cannot take care of their social need due to their ailment tend to have high depressive symptoms.

\section{Ageing and Gender Associated Risk Factors}

The occurrence of depression among patients with chronic renal failure was significantly related to ageing according to the study carried out. The finding on age as a risk factor of depression in CKD is not significant based on the measurement outcome on age. Though, the analysis outcome as reported revealed that majority of the patients studied were above 60 years and most of them have high depression score. Also, studies revealed gender as significant risk factor associated with depression in CKD. The studies examined both male and female subjects diagnosed with chronic renal failure; and from their analysis they found that most of the female subjects in their studies presented high depressive symptoms compared to their male counterparts.

\section{Ethnic Risk Factors}

Only one study revealed that ethnic background of an individual has significant correlation with depression in CKD. The Kop et al. investigated their subjects based on their ethnic background and classification. The outcome analysis shows that participants who belong to black race presented high score of depression compared with those that belongs to another race than black.

\section{Life Style Associated Risk Factors}

During synthesis and analysis of data from the included studies; three studies identified physical inactivity which is refer to as sedentary life as significant risk factor associated with depression in CKD. These studies were. The studies examined the physical functions of patients diagnosed with CKD in which the key data from both studies show that majority of participants were inactive and as result they have high depressive symptoms. Moreover, the researchers observed that the high depressive symptoms presented by subjects due to sedentary life are secondary to fatigue as well as dialysis complications.

\section{Treatment Associated Risk Factors}

Treatment is an important factor associated with depression among CKD patients. It can be a primary risk factor of depression in CKD as well as influence the emergence of other significant risk factors as it has been observed in this review. Two studies which were conducted explicitly stated in their studies that RRT and the procedure involved, were found to have significant relationships with the onset of depression among CKD patients. The study by Amira confirmed that patients who are transiting onto dialysis and those receiving dialysis as intervention were found to have high depressive episode irrespective of the dosage. Likewise, depression in CKD was found to be associated with mode of vascular access used for renal dialysis. It was revealed that having catheter pass in the groin area or on the chest is stressful and uncomfortable to bear; these methods increase the risk of depression among CKD patients.

\section{Religious Belief and Psychological Associated Risk Factors}

One study revealed that patients diagnosed with chronic renal failure that have no religious belief have high incidence 
rate of depression; this was the study conducted. The outcome analysis shows that CKD patients that have strong belief are likely to have better control over any physical and psychological challenges compared to those without belief. The study revealed that depression among CKD patients is significantly associated with frequent hospitalization which mostly CKD are faced with as a result of comorbid illnesses associated with their ailment and treatment modality which affects their mental capacity hence influencing the onset of depression among them. Additionally, revealed that educational status of patients with CKD determine their depressive level. The outcome analysis shows that low of level education specifically below high school is a significant risk factor of depression in CKD.

\section{Discussion}

Identifying the risk factors which are associated with depression among CKD patients was the main focus of this systematic review. The outcome of this study demonstrated that, most of the results which emerged are significant. Of the total number of studies included in this review 20 risk factors were identified; out of which 18 of the identified risk factors were significant considering the measurement outcome from each of the studies. The findings are consistent with the results from other studies. Also, the findings which emerged from this study are not strange or surprising because CKD is a chronic medical condition which is irreversible. Dervisoglu reported that patients diagnosed with CKD are often depressed as a result of poor prognosis and high risk of mortality in these groups of patients. It is interesting to note that even though the majority of the identified risk factors are significant their usefulness to the subject matter of this study differs. This therefore implies that some of the risk factors are more powerful than others. As a result, the evidence synthesize of the extracted data will be discussed according to the strength or power of each risk factor. A total of 11 risk factors according to their p-value and one study calculated using odd ratio were classified as very strong risk factors. To begin with low level of testosterone among male patients with CKD has been found to be the key determinant of depression in CKD. Only one study conducted by Afsar reported on the effect of low testosterone on male patients out of the eleven studies included in this review. Afsar observed that the reduction in the production of testosterone is associated with disease severity. The finding in Afsar's study was that low testosterone among CKD patients is high in stages 4 and 5 of CKD. According to Afsar testosterone is an important hormone which has significant impact on learning ability of individual and effective memory. Therefore, the deficiency of testosterone may result in poor cognitive function and high depressive symptoms. The assertion of Afsar regarding the onset of depression in CKD as a result of low testosterone is astonishing; as it revealed that low testosterone in male patients with CKD result in decrease neural activity which leads to depression. Whereas, Fernandes maintained that depression among male patients with CKD is associated with erectile dysfunction which is likely to be associated with low level of testosterone as a sex hormone in male.

Some of the very strong identified risk factors in this review are; low body mass index, low quality of life and fatigue these risk factors were identified by Chen the risk factors were classified as very strong risk factors because their $p$-value was smaller $(p<0.001)$. Besides, sleep disorder as reported by Chiang as well sedentary life reported by Kop and Young were also classified as very strong risk factors. All the identified physiological risk factors in this review are of the same course which means they are correlated. The physiological risk factors are strongly related with the biological transformation which occurred in CKD. It is possible that these risk factors were relatively associated with chronic kidney disease complications and/or dialysis complications which are likely to have the potentials to trigger the incidence of depression among these groups of patients. This assertion is consistent with the findings by Nouwen in their systematic review in which it was found that the onset of depression among patients with diabetic is relatively associated with diabetic complications; which are mostly, physiological or physical in nature. Other very strong risk factors identified were not physiological rather they are; psycho and/or socioeconomically inclined. These are: ethnics, gender, marital status and educational risk factors as reported by Kop. Frequent hospitalization reported by Nowak, Adamczak, Wiecek and economical risk factors reported by Sezer are also termed as very strong risk factors in this study. They have similar measurement outcome with the physiological risk factors as identified in this review. The result of Lopes et al. (2010) also reported on gender same as Kop. The result on ethnic risk factor suggested race as significant risk factor to the onset of depression among patients diagnosed with CKD; specifically the result show that black patients presented high score of depression compared to their white counterparts. During the course of this study there was no study found or known to have supported this theory based on scientific principles or rationale.

However, this risk factor remained useful considering the report by Abdel-Kader, Unruh \& Weisbord in which the researchers revealed that in the United State of America the incidence and intensity of chronic kidney disease is high among African Americans. This, therefore, implies that the incidence of depression is likely to be associated with the race of the people secondary to the severity of the disease. Moreover, in another study conducted in Brazil by Andrade \& Sesso the authors investigated the attitude of white and black patients diagnosed with chronic kidney disease in order to assess their level of compliance with treatment. The authors found that black patients have poor attitude to treatment as their level of compliance to medical intervention is very low in comparison with the white patients. This could be deduced as the pathway for the increase disease burden among the black patients with CKD; which may likely increase the chances of occurrence of depression among this group of people. This study has established that gender 
plays an essential role toward occurrence of depression in CKD. The studies which reported that gender has a very strong association with depression are; Kop and Lopes as mentioned above. Both studies reported that female patients with CKD presented high score of depression compared to the male patients. The findings of the two studies on gender are consistent with the previous study reported by Cukor in which; the researchers noted that female patients diagnosed with irreversible kidney disease on renal replacement therapy have negative perception toward their illness outcome which make them more anxious and depressed than male patients with CKD. Secondly, the researchers explained that female patients with CKD present high percentage of neurological and hormonal impairment which appears to be a major source of stress among female patients compared with their male counterparts. Furthermore, marital status of CKD patients has been found to be an essential risk factor which influences the incidence of depression in CKD. The main stream theory suggested that CKD patients who have no life partner or those that live alone present high depressive symptoms compared to those that live with their partners or spouse. The high depressive affect identified among single patients and those that live alone could be due to the fact that CKD patients are physically in active which implies that they need both physical and psychological support to be able to withstand the life challenges associated with their ailment (CKD).This therefore, connote that CKD patients who live alone or those who are single lack emotional and social support from their suppose or love one's which make them vulnerable to depression.

Educational and economic factors are discussed as very strong risk factors which are associated with depression in CKD considering the disease characteristic and treatment implications in CKD. It can be understood that the literacy level of the people and/or the level of awareness they have is a significant way to determine their health status (health behavior). These assertions is consistent with the a cancer study reported by Sanderson in which it was found that people whose educational level is low tend to have poor health seeking behavior compared to those who are highly educated. Likewise, according to Sanderson et al's study low literacy level is one of the major risk factors which increase the occurrence of cancer among adults in the United Kingdom. In this study it was established that economic status of patients diagnosed with CKD determined their level of exposure to depression as reported by Sezer. Though, Sezer finding focused on those patients with CKD that cannot carter for their families due to the disease burden and large family size in most of the cases. Additionally, Sezer finding supported the theory which suggested that lack of financial capacity among CKD patients result in withdrawal or noncompliance with medication especially those that are on RRT Mc kercher, Sanderson \& Jose. Also, noncompliance with medication due to lack of financial support has been found to be an instrumental stressor which have the potential of increasing the risk of depression among CKD patients associated with increase disease severity. Persistent or frequent hospitalization was identified as major stressor among CKD patients which increases their risk of developing depression; as reported by Nowak, in this study. Specifically, this result is consistent with the finding in which the authors agreed that CKD patients are often depressed due to persistent hospital admission as a result of their ailment, compared to non-CKD patients.

Evidently, reported that lack of religion has been found to be very strong risk factor associated with the onset of depression among CKD patient; as it has been shown that CKD patients who lack religious belief presented high score of depressive symptoms compared to those with strong religious belief. This agrees with the theory of Koeing, which suggested that religion has the potential of reducing anxiety and depression in advance medical conditions. The implications of the most powerful (very strong) risk factors in this review strongly suggested that depression in CKD is significantly associated with physical, psychosocial and economic stressors. Furthermore, the implications show how the risk factors are correlated with each other. Also, the implications illustrated the vulnerability of CKD patients to depression and the role of religion in reducing the level stress among CKD patients. The second categories of significant risk factors identified in this review are termed as strong risk factors. Under these categories of risk factors it was identified that treatment modality has strong association with the onset of depression in CKD. Specifically, this referred to renal replacement therapy (dialysis) which is the most common treatment prescribed for patients diagnosed with irreversible kidney disease (CKD). Unfortunately, it is a strenuous and challenging procedure as reported by Amira that CKD patients on RRT are faced with challenges which have to do with being dependent on a machine and the duration of time required for the treatment. Besides, the economic burden attached to it. The challenges identified in Amira's study were primarily correlated with the onset of depression in CKD. This is consistent with previous findings by Cukor in which the authors found that CKD patients on RRT have poor compliance to treatment which resulted in high depressive affect among CKD patients. In the contrary, Koet suggested that the course of depression among CKD patients on RRT is physiologically linked with induced dialysis inflammation of cytokines and oxidative induced stress which affect the brain thereby increasing the rate of anxiety and physical inactivity; hence, depression.

Some of the risk factors classified as strong risk factors in this study were also discussed under very strong risk factors. These risk factors specifically include; gender, living alone or without live partner and sedentary life as reported by Chiang and Nowak, Adamczak respectively. This inconsistency between the very strong and strong risk factors is likely due to the fact that the studies under these groups used different measurement tools in assessing and evaluating the same variables with similar characteristics. This resulted in disparities between the measurement outcomes 
of the studies. Notwithstanding, the listed strong risk factors were acknowledged to show their usefulness to the research question. Additionally, depression among CKD patients has been found to be associated strongly with the disease severity as reported by Chiang. The researchers revealed that nearly $74 \%$ of their subjects with stage 4 and above CKD were depressed. This result is consistent with the finding of Mckercher, Sanderson in which the researchers explained that depression among CKD patients has strong correlation with the disease morbidity and poor prognosis. A strong association has been found between age, vascular access and depression in CKD. In the study conducted by Nowak, Adamczak the researchers found that in their samples older patients above 60 years were more depressed as a result of increased morbidity which is likely aggravated by ageing. However, in a previous study by Drayer it was found that CKD patients who are young are more likely to suffer depression then older patients; this is because the low quality of life affect in CKD is high among the younger patients than it is among the older ones. The vascular access associated depression in CKD is mostly found among CKD patients who receive haemodialysis through the use of temporary vascular access, which are; femoral, internal jugular or central line vascular access. The temporary vascular accesses are difficult to manage and as the name implies, they are not permanent which means they have live time to stay on after which they have to be replaced unlike the permanent access (AV Fistula, Graft). This, therefore, implies that CKD patients with temporary vascular access spent more time in hospital which makes them more likely to develop depression compared to those with permanent access. This assertion is in line with the theory of Wasse which suggested that CKD patients with temporary vascular access for dialysis have more tendencies of reduce physical and social function. Also, it was found that this group of patients are likely to suffer sleep disturbance, inadequate dialysis and increase disease severity which increases their risk of depression.

It was found that CKD patients are mostly dependent on their carers because of the challenges associated with their disease condition and treatment which make them vulnerable to the risk of depression. Sezer findings are consistent with the observations of Abu Saif in which it was observed that patients diagnosed with irreversible kidney disease are dependent on care providers which include; medical and paramedical staff due to lack of physiological and social functions which made them frustrated and then depressed. The implications of the strong significant risk factors suggest the need for physical and psychosocial support for CKD patients. What was not found in this review was the correlation of serum albumin with low body mass index (LBMI) and the association of low serum albumin with reduce quality of life among CKD patients and how these relate with the risk of depression in CKD. Also, the correlation between high urea level and the dosage of dialysis was not found in this review. The implication of this is that some of the physiological factors that are likely to influence the onset of depression in CKD may remain unclear. The general implications of the findings which emerged from this study have significant relevance towards answering the research question. Therefore, the implications are useful in the field of public health practice in terms of policy formulation and recommendations. The findings also have benefit of improving individual skills by enhancing their professional input in the course of practice. It was established that depression in CKD is a complex issue because of the existing symptomatic similarities between uraemia and depression as reported. Furthermore, noted that the complexity makes the diagnosis of depression in CKD more problematic among individual victims. Hence, the implications of the study findings cannot be overemphasized in the area of public health practice.

The implication of the study findings focuses on the impact of physiological changes regarding the incidence of depression among CKD patients. For instance, male patients who are diagnosed with CKD have low secretion of sex hormone which decreases their sexual urge. The physiological malfunction of the kidney due to CKD also resulted in low serum albumin; which negatively affects the depressive mood of CKD patients hence increases their risk of depression. Though, the measurement outcome of this theory is not significant. The implications of the study findings will also influence further research with a view to understanding some of the physiological challenges in CKD as well as to develop strategies to manage depression in CKD. Moreover, the study findings have shown that CKD patients have low quality of life which made them more vulnerable to social, physical and economic difficulties. The outcomes of this study will encourage enactment of policies by the policy makers that will aim at empowering patients with CKD and their relations; in order to address their social and economic challenges as a result of their ailment. Interestingly, the study findings show that religion plays a vital role to the onset of depression in CKD because; people who do not have any religious belief were found to have high depression score compared to those with good religious background. For this reason, the findings will suggest active involvement of religious bodies for the management of depression among CKD patients. It was understood from this study that CKD is a chronic medical illness and that patients with CKD are mostly on maintenance dialysis. This intervention is challenging which made life difficult for patients with CKD. The outcome of the difficulties encountered by CKD patients due to treatment burden make them more likely to be depressed compared to those from healthy population. The study findings in this respect will enable health professionals and even the policy makers' device means through which the burden attached to RRT will be minimised in order to improve the quality of life of patients living with CKD. Most importantly the implications of the study's findings would likely enhance the development of preventive measures against CKD. This would be achieved through public empowerment and improve clinical interventions with a view to addressing the 
chances of progression of kidney disease from acute to chronic. In fact reducing the disease progression from acute to chronic would help to address the incidence of depression.

The study limitations are linked with the methodology and the key findings of the included studies. To start with this study was aimed to identify the risk factors of depression among CKD patients; therefore, cross-sectional studies may not be suitable to achieve this task. Gordis states, that cross-sectional study is a prevalence study which is not suitable for establishing causal inference of a disease or an event. Likewise, Gordis suggested that cohort study is open to possibilities of systematic errors because some participants may drop out which may lead to inconsistency and chance of confounding due to multiple causation. Furthermore, having observed the study designs of the included studies the limitations are evident. Firstly, the study of Afsar has evidence of systematic error because the author selected only male patients with CKD; besides, the criteria for selection of participants was age specific which is between 39 and 65 years. These criteria are likely to cause potential risk of selection bias, because there is likely chance of excluding potential participants. This barrier may leads to miss-presentation of target population which may likely affect the reliability of the study outcome. In a related study by Aggnis the researchers noted that one of the measurement tool they used, which is Centre for epidemiological studies-Depression scale cannot measure causation of depression rather it only measure the features of depression. This make the outcomes from Agganis et al.'s study confounding because there is likely hood that the features presented by their study sample may be due to uraemia not depression per say. This is a very important limitation in this study as it was reported earlier in this systematic review that depressive symptoms are very much similar with uremic symptoms. Therefore, Centre for epidemiological studies-Depression scale is not a gold standard tool for diagnosing depression as such the results obtained using this tool may be questionable. Also, Kang et al. explained that they have employed the use of self-report information from patients which proves evidence of the use of antidepressants; by their participants as a measurement tool for identifying depression among study group. This strategy may lead to limitation because it may likely exclude some potential subjects if they are unable to report the use of antidepressant; or in situation where the subjects intentionally decline to give accurate information. Similarly, the use of antidepressant could be as a result of events other than those associated with depression in CKD. Therefore, a systematic error may likely occur due to information bias and wrongful collection of data considering the procedure involved in the study.

It is pertinent at this point to state that one out the eleven articles included in this systematic review has issue with response rate which may raise concern with power analysis and robustness of the study procedure (Burns \& Grove 2001; Polit \& Beck 2004). The study with low response is the one conducted by Sezer the study has less than $60 \%$ response rate from participants. The study was included because according Bowling response rate is not an explicit barrier for excluding a study; however, Bowling confirmed that a response rate above $70 \%$ is most appropriate for health research. Moreover, another limitation to this review was linked with the recruitment procedure adopted by Young. The researchers in their study enrolled participants with CKD based on the inference of causality which is diabetic nephropathy. In this study the causality has positive association with the outcome which is depression. Therefore, the study has a confounding issue which appeared to be the causal path to the risk factor and may result in mixing of effects considering the generalizability of the study findings. This is a major difficulty experience when conducting observational research. Additionally, not enough literatures were explored to support the rationale for this review; as there where limited secondary studies done in the area of depression on CKD which could be viewed as a limitation. However, the rationale for this review was made clear and focus towards achieving the review's aims and objectives. Similarly, the timeline and language barrier set in the inclusion and exclusion criteria for this review is likely to result in the exclusion of some useful information. On the issue of time line, the tendency to miss out relevant articles is very much likely and also it is possible that relevant primary articles were excluded because they were not published in English language. Though, the reason for setting these criteria was to access the must up to date articles relevant to the research question. Besides, to achieve a wider understanding of the topic and the lessons learnt from it. Despite, the weaknesses of this review it has some useful implications to the readers considering the findings which materialized.

To start with, the findings will suggest to the readers that patients with CKD are faced with numerous difficulties; which are as a result of their ailment and intervention. Also, it will suggest to readers that the difficulties experienced by CKD patients' influences the onset of depression in CKD. Similarly, it will inform readers that the difficulties could either be dependent or independent risk factors to the incidence of depression in CKD. Additionally, the findings will suggest that the identified risk factors are likely to increase the occurrence of depression among CKD patients. Moreover, the findings will benefit the readers on the usefulness of psychological reassurance and counselling of CKD patients before they commence RRT; in order to prevent or minimise the onset of depression associated with the treatment burden (RRT). The findings will suggest to the readers the benefit of physical and economic support to CDK patients who are diagnosed with depression with a view to improving their quality of life.

\section{Conclusion}

The occurrence of chronic kidney disease is on the increase worldwide which made the disease a public health issue to deal with. Patients diagnosed with CKD are often depressed due to disease and treatment burden. Chronic kidney disease patients are left with only two options for their optimum survival which are dialysis or 
renal transplantation. These interventions are stressful, challenging and economically demanding most especially dialysis which is the common intervention received by the majority of CKD patients. Detecting depression among CKD patients is problematic because the depressive symptoms and uremic symptoms are very much similar. The limitations of this review are mostly associated with the designs and methodology of the individual studies included; as well as the procedure adopted during the course of screening and selection of the included studies. The key implications of this study include creating awareness on the incidence of depression among CKD patients and its impact on the patients' outcome. Also, the study will benefit public health practitioners to develop measures which will enhance prevention and improvement of health in order to address the incidence of kidney failure in the public. Similarly, the implication of this study will benefit the service providers so they can differentiate the disparities between depressive and uremic symptoms. Most importantly the implication of this study will enhance early detection of depression in CKD in order to improve on the quality of life of victims. Lastly, this study has spiritual implication on the life of CKD patients with depression.

\section{References}

1. Abdel Kader K, Unruh ML, Weisbord SD (2009) Symptom burden depression and quality of life in chronic and end-stage kidney disease. Clinical Journal of the American Society of Nephrology CJASN 4(6) 1057-1064.

2. Afsar B (2013) Relationship between total testosterone, cognitive function, depressive behavior, and sleep quality in chronic kidney disease patients not on dialysis. Clinical and Experimental Nephrology 17(1): 59-65.

3. Agganis BT, Weiner DE, Giang LM, Scott T, Tighiouart H, et al. (2010) Depression and cognitive function in maintenance hemodialysis patients. American Journal of Kidney Diseases 56(4): 704-712.

4. Amiya RM, Poudel KC, Poudel Tandukar K, Pandey BD, Jimba, M (2014) Perceived family support, depression, and suicidal ideation among people living with HIV/AIDS: A cross-sectional study in the kathmandu valley, Nepal. PloS One 9(3): e90959.

5. Amira $O$ (2011) Prevalence of symptoms of depression among patients with chronic kidney disease. Nigerian Journal of Clinical Practice 14(4): 460-463.

6. Andrade C, Sesso R (2012) Depression in chronic kidney disease and hemodialysis patients. Psychology 3(11): 974-978.

7. Beck AT, Steer RA, Brown GK (2006) Beck Depression Inventory.

8. Bowling A (2002) Research methods in health: Investigating health and health services. In Bowling A(Eds.), $\left(2^{\text {nd }}\right.$ edn.), Berkshire: Open University Press, United Kingdom.

9. Bowling A (2009) Research methods in health: investigating health and health services. In Bowling A (Eds.), ( $3^{\text {rd }}$ edn.), Berkshire: Open University Press United Kingdom.

10. Burns N, Grove SK (2001) The practice of nursing research: conduct, critique, \& utilization. In: Burns N, Grove SK (Eds.) ( $4^{\text {th }}$ edn.), Philadelphia: Saunders.

11. Burns N, Grove SK (2005) The Practice of nursing research: conduct, critique \& utilization. In: Burns N, Grove SK(Eds.) ( $5^{\text {th }}$ edn.), St Louis: Elsevier, USA.

12. Burns N, Grove SK (2009) The practice of nursing research: appraisal, synthesis, \& generation of evidence. In: Burns N, Grove SK (Eds.) $\left(6^{\text {th }}\right.$ edn.), Missouri: Saunders.
13. Chaudhry S (2012) Chronic kidney disease (CKD).

14. Chen C, Tsai Y, Hsu H, Wu I, Sun C, et al. (2010) Depression and suicide risk in hemodialysis patients with chronic renal failure. Psychosomatics 51(6): 528-528. e6.

15. Cherry K (2014) What is the diagnostic and statistical manual (DSM)?

16. Chiang H, Livneh H, Yen M, Li T, Tsai T (2013) Prevalence and correlates of depression among chronic kidney disease patients in Taiwan. BMC Nephrology 14(1): 78.

17. Cormack DFS (1991) The research process in nursing. In: Cormack DFS (Eds.), ( $2^{\text {nd }}$ edn.), Oxford: Blackwell, United Kingdom.

18. Crombie IK, Dvies HTO (1996) Research in health care: design, conduct and interpretation of health services research. Chichester: John Wiley \& Sons.

19. Cukor D, Cohen SD, Peterson RA, Kimmel PL (2007) Psychosocial aspects of chronic disease: ESRD as a paradigmatic illness. Journal of the American Society of Nephrology JASN 18(12): 3042-3055.

20. DePoy E, Gitlin LN (1994) Introduction to research: multiple strategies for health and human service. St Louis: Mosby.

21. Dervisoglu E, Kir HM, Kalender B, Eraldemir C, Caglayan C (2008) Depressive symptoms and proinflammatory cytokine levels in chronic renal failure patients. Nephron Clinical Practice 108(4): c272-277.

22. Fabrazzo M, De Santo RM (2006) Depression in Chronic Kidney Disease. Seminars in Nephrology, 26(1): 56-60.

23. Fernandes GV, Dos Santos RR, Soares W, De Lima LG, Macêdo D, et al. (2010) The impact of erectile dysfunction on the quality of life of men undergoing hemodialysis and its association with depression. The Journal of Sexual Medicine 7(12): 4003-4010.

24. Fountoulakis KN, Samolis S, Kleanthous S, Kaprinis SG, St Kaprinis, et al. (2001) Reliability, validity and psychometric properties of the greek translation of the zung depression rating scale. BMC Psychiatry 1(1): $1-8$.

25. Gerrish K, Lacey A (2010) The research process in nursing. (6 $6^{\text {th }}$ edn.), Oxford: John Wiley \& Sons.

26. Gordis L (2004) Epidemiology. (3 ${ }^{\text {rd }}$ edn.), Philadelphia: Elsevier Saunders.

27. Hallan SI, Dahl K, Oien CM, Grootendorst DC, Aasberg A, et al. (2006) Screening strategies for chronic kidney disease in the general population: Follow-up of cross sectional health survey. BMJ (Clinical Research Ed.) 333(7577): 1047.

28. Hedayati SS, Minhajuddin AT, Toto RD, Morris DW, Rush AJ (2009) Prevalence of major depressive episode in CKD. American Journal of Kidney Diseases 54(3): 424-432.

29. Heck G, Judd M, Moule P (200) Making sense of research: an introduction for health and social care practitioners. $\left(2^{\text {nd }}\right.$ edn.), Sage Publications, London, UK.

30. Jacobsen KH (2012) Introduction to health research methods: a practical guide. Jones and Bartlett Learning, London, UK.

31. Katon WJ (2011) Epidemiology and treatment of depression in patients with chronic medical illness. Dialogues in Clinical Neuroscience 13(1): 7-23.

32. Kang EW, Abdel-Kader K, Yabes J, Glover K, Unruh M (2012) Association of sleep-disordered breathing with cognitive dysfunction in CKD stages 4-5. American Journal of Kidney Diseases 60(6): 949-958.

33. Kellerman QD, Christensen AJ, Baldwin AS, Lawton WJ (2010) Association between depressive symptoms and mortality risk in chronic kidney disease. Health Psychology 29(6): 594-600.

34. Kop WJ, Seliger SL, Fink JC, Katz R, Odden MC, et al. (2011) Longitudinal association of depressive symptoms with rapid kidney function decline and adverse clinical renal disease outcomes. Clinical Journal of the American Society of Nephrology: CJASN 6(4): 834-844. 
35. Lakoa RM, Noubiap JJN, Fang Y, Ntone FE, Kuaban C (2013) Prevalence and correlates of depressive symptoms in HIV-positive patients: A crosssectional study among newly diagnosed patients in Yaoundé, Cameroon. BMC Psychiatry 13(1): 1-7.

36. Levey AS, Coresh J, Balk E, Kausz AT, Levin A, et al. (2003) National kidney foundation practice guidelines for chronic kidney disease: Evaluation, classification, and stratification. Annals of Internal Medicine, 139(2): 137-147

37. Lopes GB, Matos CM, Leite EB, Martins MT, Martins MS, et al. (2010) Depression as a potential explanation for gender differences in healthrelated quality of life among patients on maintenance hemodialysis. Nephron Clinical Practice, 115 (1): c35-40.

38. Lucas PJ, Baird J, Arai L, Law C, Roberts HM (2007) Worked examples of alternative methods for the synthesis of qualitative and quantitative research in systematic reviews. BMC Medical Research Methodology 15 7-4.

39. Luciano T (2011) Doing a literature review: Releasing the social science research imagination. Evaluation \& Research in Education 24(4): 303304.

40. Maltby J, Williams GA, Mc Garry J, Day L (2010) Research methods for nursing and healthcare. London: Pearson.

41. Manea L, Gilbody S, McMillan D (2012) Optimal cut-off score for diagnosing depression with the patient health questionnaire (PHQ-9): A meta-analysis. CMAJ Canadian Medical Association Journal 184 (3): E191-196.

42. Mathew TH, Corso O, Ludlow M, Boyle A, Cass A, et al. (2010) Screening for chronic kidney disease in Australia: A pilot study in the community and workplace. Kidney International 77: S9-S16.

43. MC Kercher C, Sanderson K, Jose MD (2013) Psychosocial factors in people with chronic kidney disease prior to renal replacement therapy. Nephrology (Carlton) 18(9): 585-591.

44. MCMH BA ASK, Thabet AM, Vostanis P (2007) Depression Among EndStage Renal failure patients in El-Shifa Hospital Gaza Strip 2(4): 179.

45. Mifflin N, Shunker S (2014) Continuous renal replacement therapy.

46. Nouwen A, Winkley K, Twisk J, Lloyd C, Peyrot M, et al. (2010) Type 2 diabetes mellitus as a risk factor for the onset of depression: A systematic review and meta-analysis. Diabetologia 53 (12): 2480-2486.

47. Nowak $七$, Adamczak M, Więcek A (2013) Is inflammation a new risk factor of depression in haemodialysis patients? International Urology and Nephrology 45 (4): 1121-1128.

48. Pagels AA, Soderkvist BK, Medin C, Hylander B, Heiwe S (2012) Healthrelated quality of life in different stages of chronic kidney disease and at initiation of dialysis treatment. Health Qual Life Outcomes 10: 71.

49. Palmer S, Vecchio M, Craig JC, Tonelli M, Johnson DW, et al. (2013) Prevalence of depression in chronic kidney disease: systematic review and meta- analysis of observational studies. Kidney Int 84(1): 179-191.
50. Park HC, Lee H, Lee JP, Kim DK, Oh K, et al. (2012) Lower residual renal function is a risk factor for depression and impaired health-related quality of life in Korean peritoneal dialysis patients. Journal of Korean Medical Science 27 (1): 64-71.

51. Polgar S, Thomas SA (1995) Introduction to research in the health sciences. In Polgar S, Thomas SA(Eds.) ( $3^{\text {rd }}$ edn.), Australia: Churchill Livingstone.

52. Polgar S, Thomas SA (2000) Introduction to research in the health sciences. In Polgar S, Thomas SA(Eds.) (4th edn.), London: Churchill Livingstone.

53. Poli DF, Beck CT (2004) Nursing research: Principles and methods. In Poli DF, Beck CT(Eds.), ( $7^{\text {th }}$ edn.), Lippincott Williams \& Wilkins.

54. Popay J, Roberts H, Sowden A, Petticrew M, Arai L, et al. (2006) Guidance on the conduct of narrative synthesis in systematic reviews. A Product from the ESRC Methods Programme Version 1.

55. Santos PR (2011) Depression and quality of life of hemodialysis patients living in a poor region of brazil. Revista Brasileira De Psiquiatria 33(4): 332-337.

56. Schieppati A, Remuzzi G (2005) chronic renal diseases as a public health problem: Epidemiology, social, and economic implications. Kidney International 68: S7-S10.

57. Sezer S, Uyar ME, Bal Z, Tutal E, Ozdemir Acar FN (2013) The influence of socioeconomic factors on depression in maintenance hemodialysis patients and their caregivers. Clinical Nephrology 80(5): 342-348.

58. Sheehan DV, Lecrubier Y, Sheehan KH, Amorim P, Janavs J, et al. (1998) The mini-international neuropsychiatric interview (MINI): The development and validation of a structured diagnostic psychiatric interview for DSMIV and ICD-10. Journal of Clinical Psychiatry 59: 22-33.

59. Taal MW (2012) Brenner \& rector's the kidney. Elsevier/Saunders Philadelphia, PA.

60. Tripepi G, Jager KJ, Dekker FW, Zoccali C (2010) Selection bias and information bias in clinical research. Nephron Clinical Practice 115 (2): c94-99.

61. UK Faculty of Public Health (2010) UK Faculty of Public Health: Learning outcomes framework.

62. Walsh M (2002) Watson's clinical nursing and related science. In: Walsh M (Eds.), (6 ${ }^{\text {th }}$ edn.), Edinburgh

63. Wen CP, Cheng TYD, Tsai MK, Chang YC, Chan HT, et al. (2008) All-cause mortality attributable to chronic kidney disease: A prospective cohort study based on 462293 adults in Taiwan. The Lancet 371(9631): 21732182 .

64. Wood GL, Habe J (1998) Nursing research: methods, critical appraisal, and utilization. In: Wood GL, Habe J(Eds.) ( $4^{\text {th }}$ edn.), Missouri: Mosby.

65. Young BA, Von Korff M, Heckbert SR, Ludman EJ, Rutter C, et al. (2010) Association of major depression and mortality in stage 5 diabetic chronic kidney disease. General Hospital Psychiatry 32(2): 119-124.

\section{ISSN: 2574-1241}

DOI: 10.26717/BJSTR.2019.15.002775

Faruk Namalam.Biomed J Sci \& Tech Res

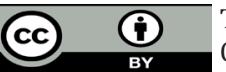

This work is licensed under Creative

Commons Attribution 4.0 License

Submission Link: https://biomedres.us/submit-manuscript.php

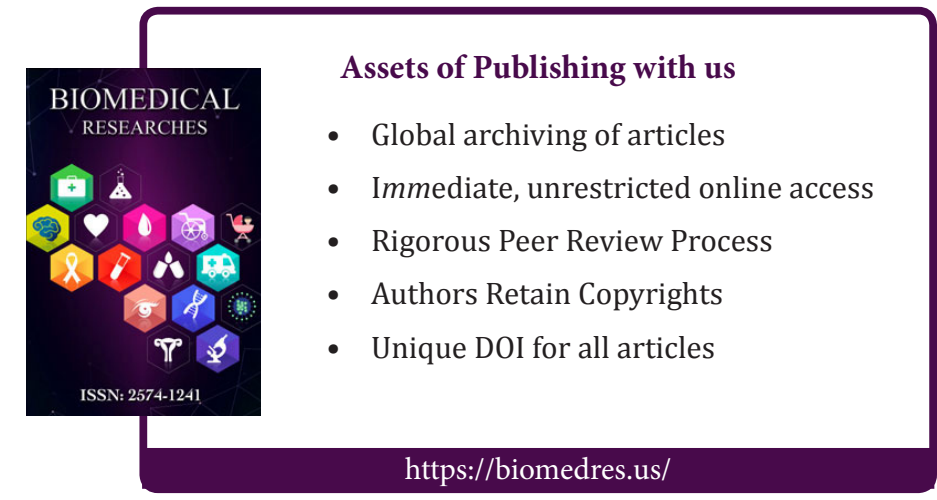

